\title{
Adjuvant chemotherapy may improve prognosis after resection of stage $I$ lung cancer with lymphovascular invasion
}

\author{
Shuyuan Wang, MD, ${ }^{a}$ Jianlin Xu, PhD, ${ }^{\mathrm{a}}$ Rui Wang, $\mathrm{PhD},{ }^{\mathrm{b}}$ Fangfei Qian, MD, ${ }^{\mathrm{a}}$ Wenjia Yang, MD, \\ Rong Qiao, MD, ${ }^{\mathrm{a}}$ Bo Zhang, $\mathrm{PhD},{ }^{\mathrm{a}}$ Jie Qian, $\mathrm{PhD},{ }^{\mathrm{a}}$ Keke $\mathrm{Yu}, \mathrm{PhD},{ }^{\mathrm{c}}$ and Baohui Han, $\mathrm{PhD}^{\mathrm{a}, \mathrm{d}}$
}

\section{ABSTRACT}

Objectives: This study explored the prognostic significance and adjuvant chemotherapy benefits in resected patients with stage I non-small cell lung cancer with lymphovascular invasion.

Methods: A total of 2633 patients who received complete resection with pathologic stage I non-small cell lung cancer in the Shanghai Chest Hospital (2008-2012) were enrolled in the study, of whom 222 were diagnosed with lymphovascular invasion. By using the Kaplan-Meier method and Cox proportional hazard regression model, we explored the impact of lymphovascular invasion on prognosis and determined if the use of adjuvant chemotherapy is associated with improved outcomes in patients with lymphovascular invasion. A propensity score-matched analysis was implemented to reduce the selection bias.

Results: Patients with lymphovascular invasion had an unfavorable overall survival and recurrence-free survival in stage I non-small cell lung cancer. Multivariate Cox analysis indicated that lymphovascular invasion was an independent poor prognostic factor for recurrence-free survival (hazard ratio [HR], 2.06; 95\% confidence interval $[\mathrm{CI}], 1.58-2.71 ; P<.001)$ and overall survival $(\mathrm{HR}, 2.04 ; 95 \% \mathrm{CI}$, $1.45-2.87 ; P<.001)$ in patients with stage I. After using propensity scorematched pairs, analysis of 65 pairs of patients with lymphovascular invasion indicated a beneficial recurrence-free survival (HR, 0.33; 95\% CI, 0.16-0.67; $P=.002)$ and overall survival (HR, 0.30; 95\% CI, 0.12-0.74; $P=.009$ ) from adjuvant chemotherapy.

Conclusions: Lymphovascular invasion was correlated with poor prognosis in patients with stage I non-small cell lung cancer. For such patients, adjuvant chemotherapy was associated with improved survival. Our study suggests that adjuvant chemotherapy might be an appropriate option for patients with stage I non-small cell lung cancer with lymphovascular invasion. (J Thorac Cardiovasc Surg 2018;156:2006-15)

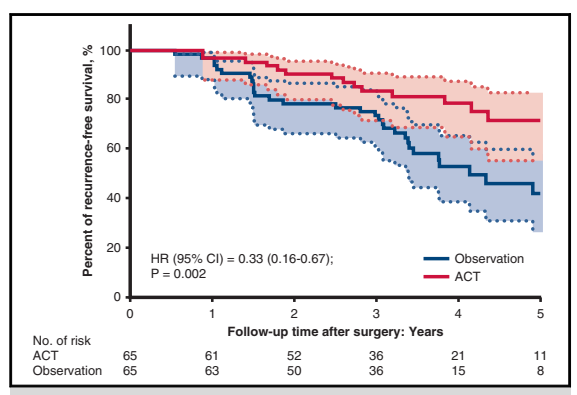

The RFS curves (ACT vs observation) in stage I NSCLC with lymphovascular invasion.

\section{Central Message}

For patients with stage I lung cancer, LVI has been reported to be a strong risk factor. ACT may improve the poor prognosis in patients with stage I lung cancer with LVI.

\section{Perspective}

This study investigated the influence of LVI in patients with stage I NSCLC based on the 8th edition of the TNM classification and whether ACT may improve the poor prognosis in patients with stage I with LVI.

See Editorial Commentary page 2016.
From the Departments of ${ }^{\mathrm{a}}$ Pulmonary, ${ }^{\mathrm{b}}$ Thoracic Surgery, and ${ }^{\mathrm{c}}$ Pathology, and ${ }^{\mathrm{d}}$ Central Laboratory, Shanghai Chest Hospital, Shanghai Jiaotong University, Shanghai, China.

This work was supported by Key Projects of the Biomedicine Department, Science and Technology Commission of Shanghai Municipality (No. 11411951200).

Presented as a poster at the 2018 European Lung Cancer Conference, Geneva, Switzerland, April 11-14, 2018

S.W. and J.X. contributed equally to this work.

Received for publication Nov 20, 2017; revisions received May 26, 2018; accepted for publication June 9, 2018; available ahead of print Aug 10, 2018.

Address for reprints: Baohui Han, PhD, Department of Pulmonary, Shanghai Chest Hospital, Shanghai Jiaotong University, Huaihai West Rd No. 241, Shanghai, China (E-mail: 18930858216@163.com).

0022-5223/\$36.00

Copyright $($ c 2018 by The American Association for Thoracic Surgery

https://doi.org/10.1016/j.jtcvs.2018.06.034
Lung cancer is one of the most common cancers and a major cause of cancer-related deaths worldwide. ${ }^{1}$ Today, with the prevalence of low-dose computed tomography (CT) for screening, patients are being diagnosed at earlier stages. ${ }^{2}$ For these patients with early-stage disease, operation is the optimal treatment. Patients with stage IA and IB non-

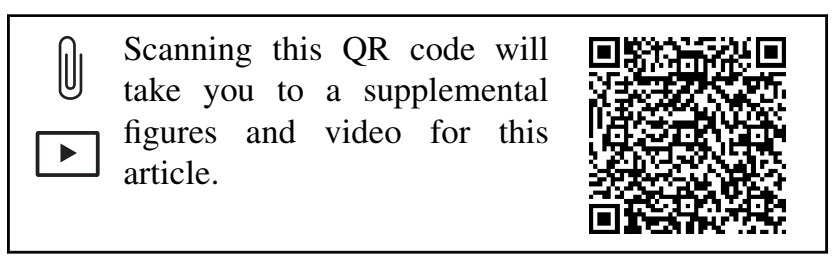




$$
\begin{aligned}
& \text { Abbreviations and Acronyms } \\
& \begin{aligned}
\text { ACT } & \text { adjuvant chemotherapy } \\
\text { CI } & =\text { confidence interval } \\
\text { CT } & =\text { computed tomography } \\
\text { HR } & =\text { hazard ratio } \\
\text { LVI } & =\text { lymphovascular invasion } \\
\text { LVI-N } & =\text { lymphovascular invasion negative } \\
\text { LVI-P } & =\text { lymphovascular invasion positive } \\
\text { NCCN } & =\text { National Comprehensive Cancer } \\
& \text { Network } \\
\text { NSCLC } & =\text { non-small cell lung cancer } \\
\text { OS } & =\text { overall survival } \\
\text { PET } & =\text { positron emission tomography } \\
\text { PSM } & =\text { propensity score matching } \\
\text { RFS } & \text { recurrence-free survival } \\
\text { VPI } & =\text { visceral pleural invasion }
\end{aligned}
\end{aligned}
$$

small cell lung cancer (NSCLC) have $82 \%$ and $66 \% 5$-year survival, respectively, according to the 7 th TNM stage. ${ }^{3}$ When compared with other malignant tumors, stage I NSCLC has a good prognosis; however, a few patients eventually die of lung cancer, potentially indicating the existence of a poor prognostic group., ${ }^{4,5}$

Previous studies have reported clinicopathologic parameters, including sex, age, smoking history, serum carcinoembryonic antigen level, extent of operation, tumor

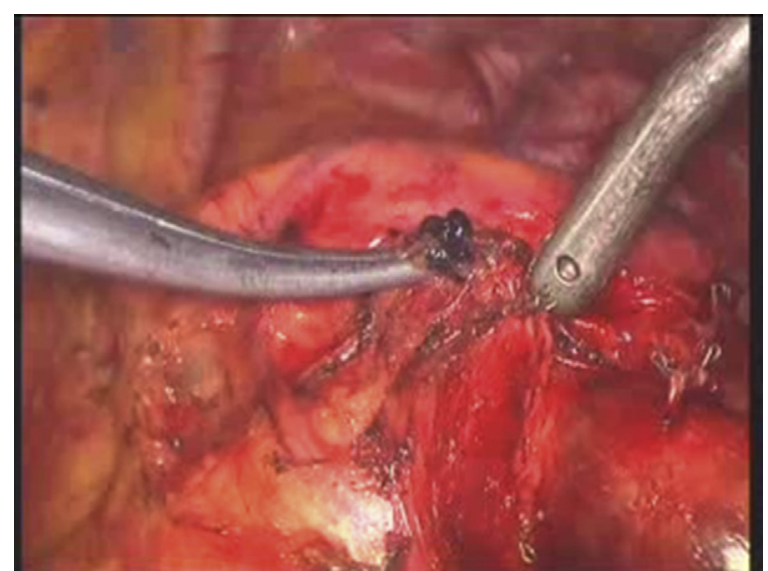

VIDEO 1. Lobectomy and lymph node dissection of left upper lobe of lung. Video available at: https://www.jtcvs.org/article/S0022-5223(18) 31779-3/fulltext.

differentiation, tumor size, visceral pleural invasion (VPI), and lymphovascular invasion (LVI), that may be related to prognosis. ${ }^{6-11}$ Of these parameters, LVI was demonstrated to be an important prognostic factor in NSCLC. ${ }^{12}$ LVI was defined as tumor growth around the vessel, destruction of vascular walls, or intravascular tumor thrombi formation that can be divided into blood vessel invasion and lymphatic vessel invasion. ${ }^{13}$ Because of the poor prognosis of LVI, some scholars suggested cataloging LVI into T stage. ${ }^{14}$

For patients with stage II to IIIA NSCLC, platinum-based adjuvant chemotherapy (ACT) is routinely recommended.

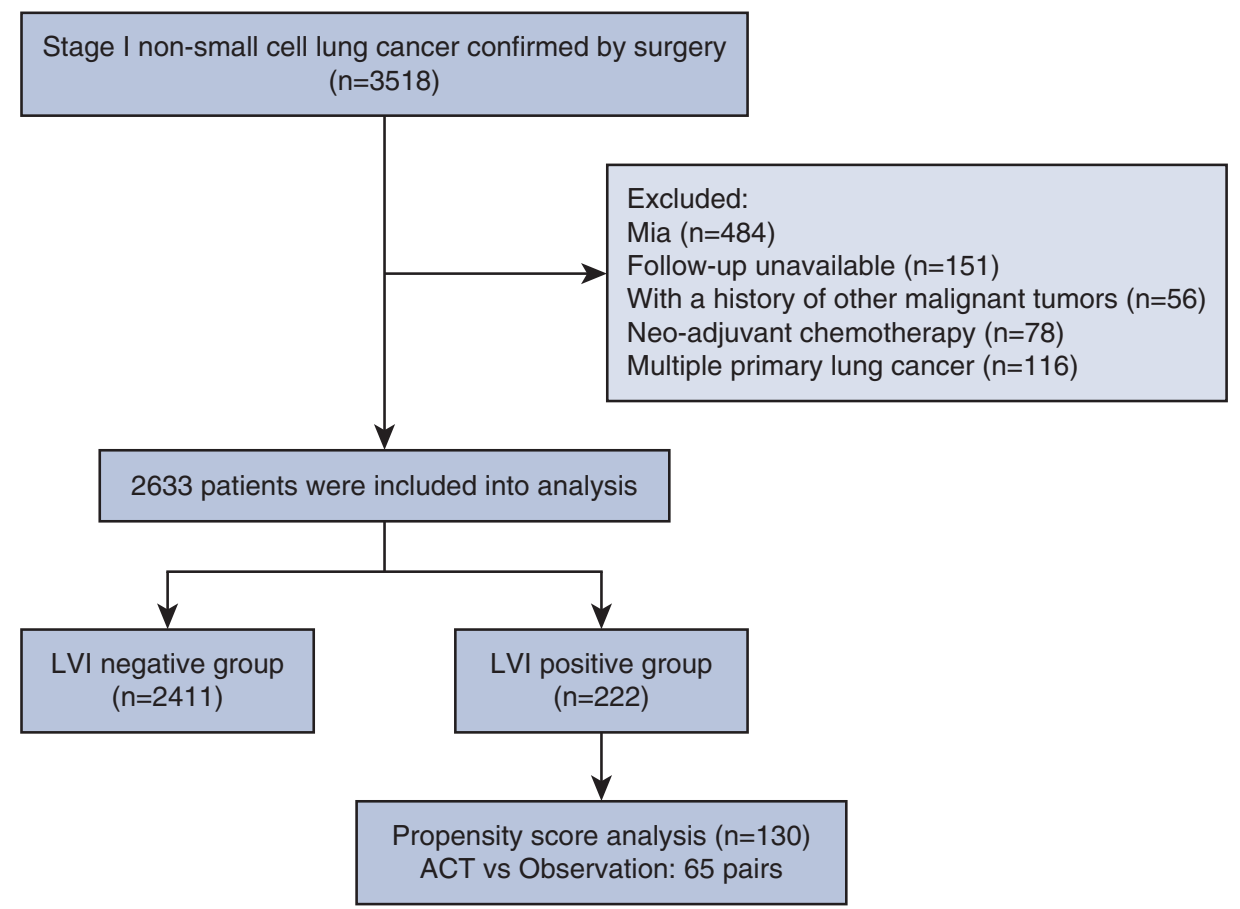

FIGURE 1. Diagram of study cohort selection step. Mia, Minimally invasive adenocarcinoma; LVI, lymphovascular invasion; ACT, adjuvant chemotherapy. 
But the benefit from ACT for those with stage I NSCLC is still lacking evidence. Several clinical trials have drawn different conclusions. ANITA showed no benefits from ACT in patients with stage IB. ${ }^{15}$ JBR. 10 showed no survival benefit from ACT for patients with stage IB, although patients with tumors larger than $4 \mathrm{~cm}$ appeared to benefit from chemotherapy. ${ }^{16}$ However, Cancer and Leukemia Group B 9633 recommended ACT for patients with stage IB who have tumors more than $4 \mathrm{~cm}$ in diameter. ${ }^{17}$ National Comprehensive Cancer Network (NCCN) guidelines recognized that chemotherapy may be considered for patients with stage IB with high-risk factors, including poorly differentiated tumors, vascular invasions, wedge resection, tumors greater than $4 \mathrm{~cm}$, visceral pleural involvement, and unknown lymph node status. There was no conclusion in the use of ACT in patients with stage IA. Studies from Japan showed that tegafur-uracil significantly improved survival in patients with stage I NSCLC, particularly those with lung adenocarcinomas greater than $2 \mathrm{~cm}$, which was revealed by randomized phase 3 trials and meta-analysis. ${ }^{18-20}$

We explored the benefits of ACT for patients with stage I NSCLC, especially those with LVI. Therefore, the aim of our study was to investigate the impact of LVI on prognosis and to determine if the use of ACT is associated with improved outcomes in patients with LVI.

\section{PATIENTS AND METHODS \\ Patients}

This study was approved by the Institutional Review Board of Shanghai Chest Hospital (Shanghai, China). We reviewed the medical records of patients who had undergone pulmonary surgery between January 2008 and December 2012 in the Shanghai Chest Hospital and restaged these patients on the basis of the 8th edition of the TNM Classification for Lung and Pleural Tumors of the Union for International Cancer Control and postoperative pathology. ${ }^{3}$ According to the 8 th TNM classification, stage IA (T1a-cNOM0) is divided into 3 groups: IA1, IA 2, and IA3, defined as $1 \mathrm{~cm}$ or less, greater than $1 \mathrm{~cm}$ but $2 \mathrm{~cm}$ or less, greater than $2 \mathrm{~cm}$ but $3 \mathrm{~cm}$ or less in greatest dimension without lymph node involvement and distant metastasis, respectively. Stage IB (T2aNOM0) is defined as tumor greater than $3 \mathrm{~cm}$ but $4 \mathrm{~cm}$ or less in greatest dimension, or tumor with any of the following features (if $\leq 4 \mathrm{~cm}$ in greatest dimension): involves main bronchus regardless of distance from the carina of the carina but without involvement; invades visceral pleura without lymph node involvement and distant metastasis.

All patients underwent complete resection, including wedge resection, lobectomy (Video 1), and more extensive lung resection with systematic ipsilateral hilar and mediastinal lymph node dissection, and there was no evidence of residual cancer macroscopically or microscopically. There were also no positive lymph nodes or distant metastasis observed. In addition, all patients underwent preoperative examination, including contrastenhanced $\mathrm{CT}$, brain magnetic resonance imaging or $\mathrm{CT}$, and abdominal CT or ultrasonography, and had good Eastern Cooperative Oncology Group performance status (0-1). Most patients underwent a radionuclide bone scan, and the remainder underwent positron emission tomography (PET) and CT. Patients were excluded if they were diagnosed with other malignant tumors or multiple primary lung cancer, received neo-ACT/ radiotherapy, or were lost to follow-up. Finally, we included 2633 patients in the statistical analysis (Figure 1).
TABLE 1. Clinicopathologic characteristics of all patients with stage I stratified by lymphovascular invasion

\begin{tabular}{|c|c|c|c|}
\hline & $\begin{array}{c}\text { LVI negative } \\
(n=2411)(\%)\end{array}$ & $\begin{array}{c}\text { LVI positive } \\
(n=222)(\%)\end{array}$ & $\begin{array}{c}P \\
\text { value }\end{array}$ \\
\hline Age, $y$, (range) & $60(31-83)$ & $60(25-81)$ & $.493^{*}$ \\
\hline $\begin{array}{l}\text { Sex } \\
\quad \text { Female } \\
\quad \text { Male }\end{array}$ & $\begin{array}{l}1163(48.2) \\
1248(51.8)\end{array}$ & $\begin{array}{l}105(47.3) \\
117(52.7)\end{array}$ & $.789+$ \\
\hline $\begin{array}{l}\text { Smoking history } \\
\text { Yes } \\
\text { No }\end{array}$ & $\begin{array}{r}693(28.7) \\
1718(71.3)\end{array}$ & $\begin{array}{r}53(23.9) \\
169(76.1)\end{array}$ & $.123 \dagger$ \\
\hline $\begin{array}{l}\text { Cancer-related comorbidity } \\
\text { Yes } \\
\text { No }\end{array}$ & $\begin{array}{r}818(33.9) \\
1593(66.1)\end{array}$ & $\begin{array}{r}72(32.4) \\
150(67.6)\end{array}$ & $.652 \dagger$ \\
\hline $\begin{array}{l}\text { Pulmonary function } \\
\text { FEV1/FVC } \geq 70 \%\end{array}$ & $2249(93.3)$ & $209(94.1)$ & $.621 \dagger$ \\
\hline $\begin{array}{l}\text { PET-CT, n } \\
\text { Yes } \\
\text { No }\end{array}$ & $\begin{array}{r}296(12.3) \\
2115(87.7)\end{array}$ & $\begin{array}{r}34(15.3) \\
188(84.7)\end{array}$ & $.191 \dagger$ \\
\hline $\begin{array}{l}\text { Procedure } 1 \\
\text { Lobectomy } \\
\text { Sub-lobectomy }\end{array}$ & $\begin{array}{c}2195(91.0) \\
216(9.0)\end{array}$ & $\begin{array}{c}208(93.7) \\
14(6.3)\end{array}$ & $.180 \dagger$ \\
\hline $\begin{array}{l}\text { Procedure } 2 \\
\text { VATS } \\
\text { Open }\end{array}$ & $\begin{array}{c}2292(95.1) \\
119(4.9)\end{array}$ & $\begin{array}{r}188(84.7) \\
34(15.3)\end{array}$ & $<.001 \dagger$ \\
\hline $\begin{array}{l}\mathrm{P} \text { or } \mathrm{C} \\
\mathrm{P} \\
\mathrm{C}\end{array}$ & $\begin{array}{c}2242(93.0) \\
169(7.0)\end{array}$ & $\begin{array}{c}214(96.4) \\
\quad 8(3.6)\end{array}$ & $.052 \dagger$ \\
\hline $\begin{array}{l}\text { Postoperative complication } \\
\text { Yes } \\
\text { No }\end{array}$ & $\begin{array}{c}43(1.8) \\
2368(98.2)\end{array}$ & $\begin{array}{c}4(1.8) \\
218(98.2)\end{array}$ & $1.00)_{\ddagger}^{+}$ \\
\hline $\begin{array}{l}\text { TNM stage } \\
\text { Stage IA1-3 } \\
\text { Stage IB }\end{array}$ & $\begin{array}{r}1482(61.5) \\
929(38.5)\end{array}$ & $\begin{array}{l}113(50.9) \\
109(49.1)\end{array}$ & $.002 \dagger$ \\
\hline Total tumor size, $\mathrm{cm} \pm \mathrm{SD}$ & $2.6 \pm 0.8$ & $2.7 \pm 0.8$ & $.317^{*}$ \\
\hline $\begin{array}{l}\text { Histology } \\
\text { Adenocarcinoma } \\
\text { Nonadenocarcinoma }\end{array}$ & $\begin{array}{r}2009(83.3) \\
402(16.7)\end{array}$ & $\begin{array}{c}202(91.0) \\
20(9.0)\end{array}$ & $.003 \dagger$ \\
\hline $\begin{array}{l}\text { VPI } \\
\text { Yes } \\
\text { No }\end{array}$ & $\begin{array}{r}752(31.2) \\
1659(68.8)\end{array}$ & $\begin{array}{r}84(37.8) \\
138(62.2)\end{array}$ & $.042 \dagger$ \\
\hline Recurrence & $420(17.4)$ & $67(30.2)$ & $<.001 \dagger$ \\
\hline Mortality & $304(12.6)$ & $42(18.9)$ & $.008+$ \\
\hline Lung cancer mortality & $272(11.3)$ & $41(18.5)$ & \\
\hline Other causes mortality & $32(1.3)$ & $1(0.5)$ & \\
\hline $\mathrm{ACT}$ & $706(29.3)$ & $148(66.7)$ & $<.001 \dagger$ \\
\hline
\end{tabular}

Nonadenocarcinoma includes squamous cell carcinoma, large cell carcinoma, and adenosquamous carcinoma. $L V I$, Lymphovascular invasion; FEVI, forced expiratory volume in 1 second; $F V C$, forced vital capacity; $P E T-C T$, positron emission tomography-computed tomography; VATS, video-assisted thoracoscopic surgery; $P$, peripheral lung cancer; $C$, central lung cancer; TNM stage, tumor-node-metastasis stage; $S D$, standard deviation; $V P I$, visceral pleura invasion; $A C T$, Adjuvant chemotherapy. *Mann-Whitney $U$ test. $\dagger$ Chi-square test. $\stackrel{\dagger}{\dagger}$ Fisher exact test. 
TABLE 2. Multivariate analyses of prognostic factors of patients with stage I non-small cell lung cancer

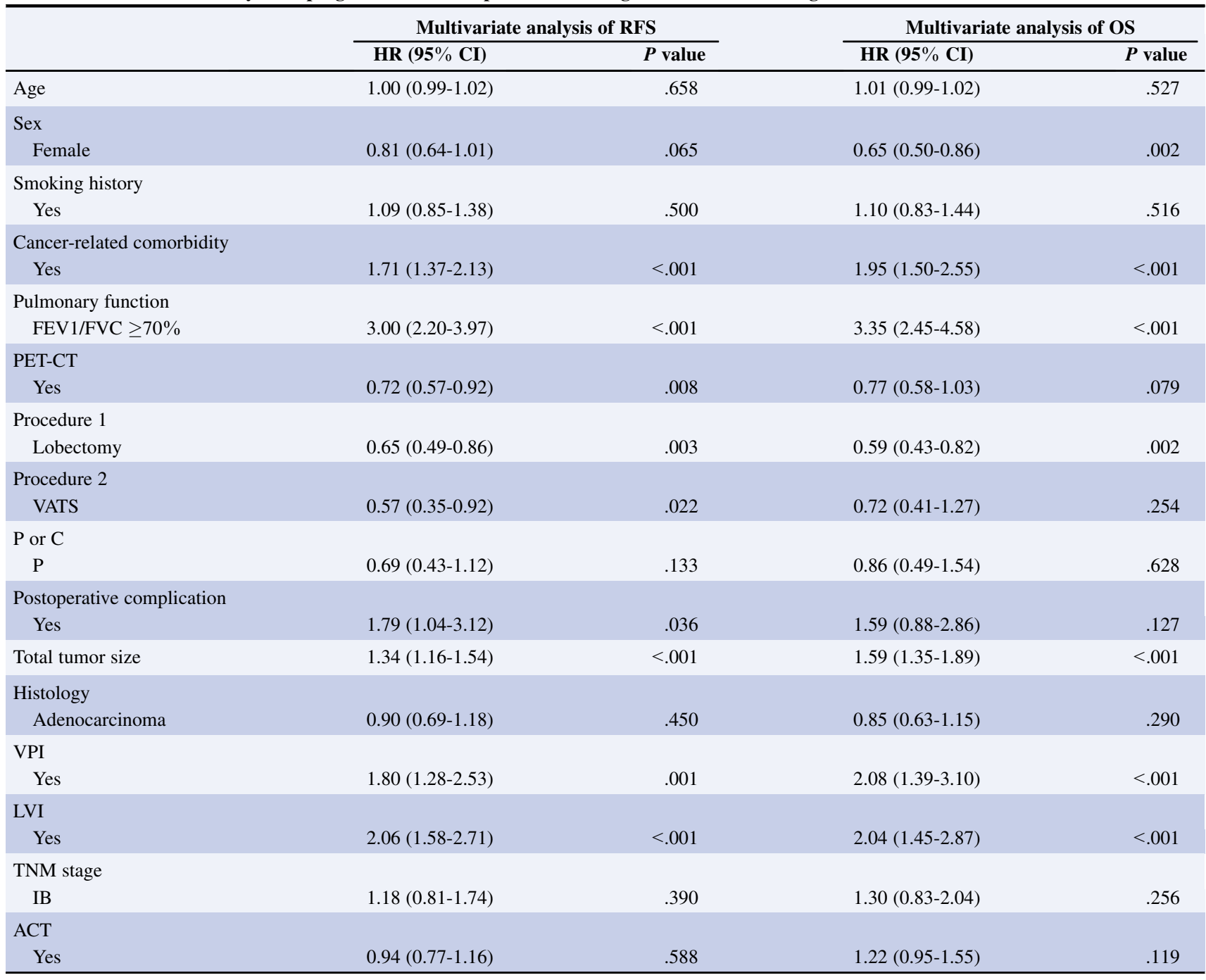

Nonadenocarcinoma includes squamous cell carcinoma, large cell carcinoma, and adenosquamous carcinoma. $R F S$, Recurrence-free survival; $O S$, overall survival; $H R$, hazard ratio; $C I$, confidence interval; $F E V I$, forced expiratory volume in 1 second; $F V C$, forced vital capacity; PET-CT, positron emission tomography-computed tomography; VATS, video-assisted thoracoscopic surgery; $P$, peripheral lung cancer; $C$, central lung cancer; VPI, visceral pleura invasion; LVI, lymphovascular invasion; TNM stage, tumor-nodemetastasis stage; $A C T$, adjuvant chemotherapy.

\section{Histopathologic Studies}

Histopathologic studies were performed according to the World Health Organization criteria. Detailed examinations of LVI were routinely performed by senior pathologists at our institution. LVI was defined as the obvious presence of tumor emboli in vessels under the microscope, regardless of whether they were blood or lymphatic vessels. If there were any doubts about diagnosis, specimens were stained with anti-D2-40 monoclonal antibody (DAKO, Carpinteria, Calif) to evaluate lymphatic vessels and Elastica van Gieson stain to confirm blood vessel invasion.

\section{Follow-up}

Follow-up was mainly conducted by patients visit and telephone. All of the patients were informed to visit our hospital or other institutions every 3 months for the first 3 years after surgery and every 6 months thereafter. Examination items, including thoracic CT, blood carcinoma embryonic antigen test, abdominal CT scan, or ultrasonography, were conducted every visit. Bone scan and cranial CT scan or magnetic resonance imaging were performed annually if there were no symptoms. PET-CT was also recognized if permitted.

We collected the clinicopathologic parameters, including sex, age, smoking history, tumor location, operative procedures, operation date, histology type, tumor size, LVI, VPI, and cancer-related comorbidities and postoperative complication. Comorbidities included hypertension, diabetes mellitus, ischemic heart disease, abnormal pulmonary function, or other diseases proved to be related to the mortality of cancer by previous studies. $^{21-23}$ Normal pulmonary function was defined as forced expiratory volume in 1 second/forced vital capacity $70 \%$ or greater.

\section{Criteria for Adjuvant Chemotherapy Treatment}

In this study, cisplatin/carboplatin-based ACT was recommended for patients. Regimen dose and cycles followed NCCN guidelines. ${ }^{24}$ At least 3 cycles of chemotherapy were considered as effective chemotherapy. 


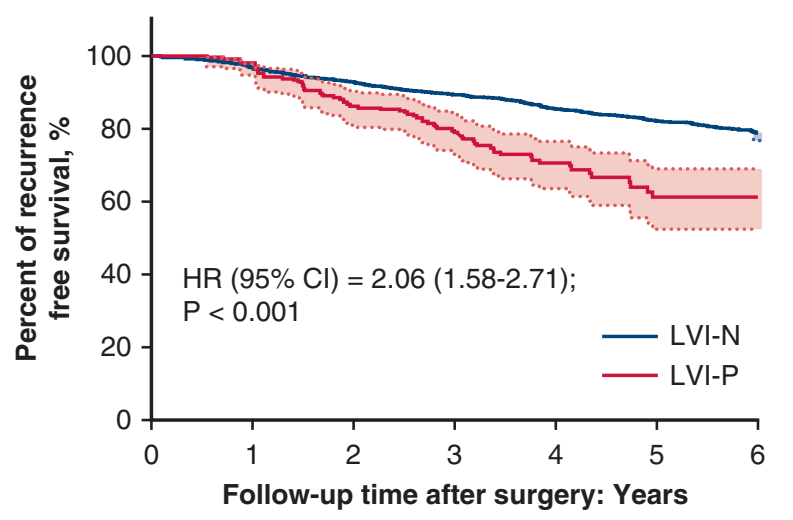

No. of risk

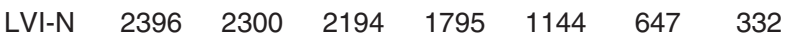

$\begin{array}{llllllll}\text { LVI-P } & 221 & 213 & 180 & 127 & 66 & 33 & 16\end{array}$

A

FIGURE 2. RFS (A) and OS (B) curves of patients with stage I NSCLC stratified by LVI. LVI-N, Lymphovascular invasion negative; LVI-P, lymphovascular invasion positive; $H R$, hazard ratio; $C I$, confidence interval.

\section{Statistical Analysis}

Data are presented as follows: Continuous variables are reported as median (range), and dichotomous variables are reported as number (percent). The chi-square test was used to compare frequencies for categoric variables, and the Fisher exact test was used for small samples. In the LVI positive (LVI-P) group, patients who received chemotherapy were younger than those in the observation group. To correct the bias of the ACT group and surgery alone group, propensity score matching (PSM) was used to balance clinical characteristics, including age, sex, smoking history, comorbidities, pulmonary function, PET-CT examination, surgery procedures, postoperative complications, histology, VPI, and tumor size. For PSM, nearest neighbor matching was selected with a caliper width of 0.2 of standard deviation. Patients in the observation group were randomly matched to those in the ACT group with 1:1 matching methods. The PSM was conducted using the package "MatchIt" of R (version 3.4.3; R Development Core Team). After PSM, McNemar's test and paired-samples $t$ test were used to analyze the propensity score-matched pairs.

Recurrence-free survival (RFS) was defined as the time from surgery to the date of the earliest recurrence or death due to any cause or the last follow-up. Overall survival (OS) was defined as the time from the day of surgery to death from any cause or the last follow-up.

The Kaplan-Meier method was applied to graphically describe the distribution of OS and RFS. The Cox proportional hazard model was used to assess the potential effects of LVI and ACT on OS and RFS after adjustment for other clinical variables.

The relative hazards and the relative 95\% confidence intervals (CIs) were calculated. SPSS statistical software, version 22 (SPSS Inc, Chicago, Ill), was used for all statistical analyses.

\section{RESULTS \\ Patient Characteristics}

The median follow-up after surgery was 61.0 months, ranging from 0.3 to 106.3 months. The demographic and clinicopathologic characteristics of 2633 patients are summarized in Table 1. A total of 1595 patients had stage IA, and 1038 patients had stage IB. The median patient age was 60 years (range, 18-85 years). Approximately half $(48.2 \%)$ of the patients were female, $84.0 \%$ were diagnosed with adenocarcinoma, and $28.3 \%$ had a history of smoking.

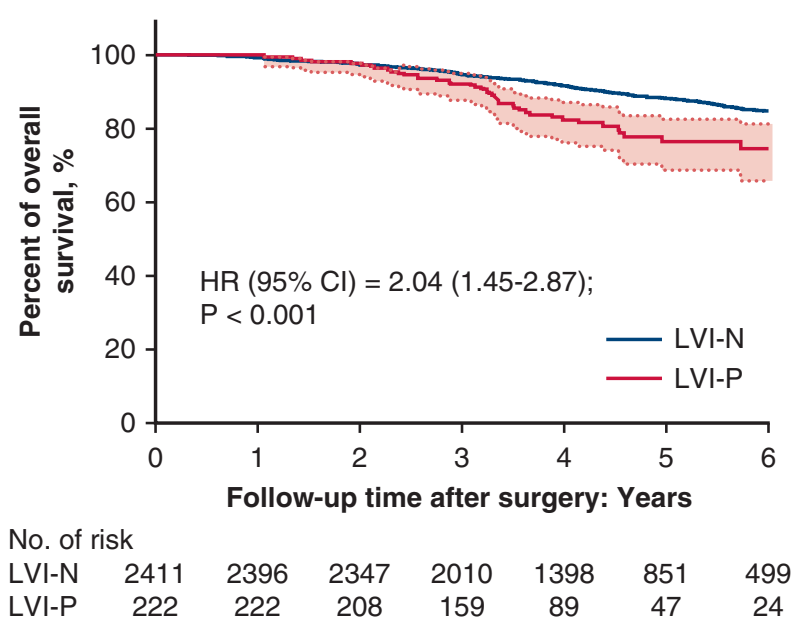

B
LVI was observed in 222 patients $(8.4 \%) ; 113(50.9 \%)$ had stage IA, and $109(49.1 \%)$ had stage IB. With increasing tumor size, the presence of LVI increases: The presence of LVI in diameter from 0 to $1 \mathrm{~cm}, 1$ to $2 \mathrm{~cm}, 2$ to $3 \mathrm{~cm}$, and 3 to $4 \mathrm{~cm}$ was $2.3 \%, 5.4 \%, 10.5 \%$, and $13.3 \%$, respectively. The 2 groups, LVI-P and lymphovascular invasion negative (LVI-N), showed a significant difference in histology $(P=.003)$ and VPI $(P=.042)$, indicating that LVI may be correlated with VPI and adenocarcinoma. The survival outcomes are summarized in Table 1.

\section{Lymphovascular Invasion Was a Poor Prognostic Factor for Recurrence-Free Survival and Overall Survival in Patients With Stage I Non-Small Cell Lung Cancer}

Univariate survival analysis was used to determine that LVI was a significantly poor prognostic factor for OS (LVI-P vs LVI-N: $P=.008$ ) and RFS (LVI-P vs LVI-N: $P<.001)$. Multivariate Cox proportional hazard regression models were performed to identify whether LVI was an independent risk factor for OS and RFS after adjusting for other clinical covariates, including sex, age, smoking history, comorbidities, pulmonary function, PET-CT examination, extent of surgery, histology, VPI, locations, postoperative complication, and TNM stage. The results are shown in Table 2. The Kaplan-Meier curves are shown in Figure 2. For all patients with stage I, the LVI-P group also had a greater risk of recurrence (hazard ratio [HR], 2.06; 95\% CI, 1.58-2.71; $P<.001$ ) (Figure 2, A), and LVI was associated with poor OS (HR, 2.04; 95\% CI, 1.452.87; $P<.001$ ) (Figure 2, $B$ ). In the subgroup of patients with stage IA1-3 NSCLC, there were significant differences in RFS (HR, 2.91; 95\% CI, 1.89-4.50; $P<.001)$ and OS 
TABLE 3. Clinicopathologic characteristics of patients with stage I non-small cell lung cancer with lymphovascular invasion before and after propensity score matching

\begin{tabular}{|c|c|c|c|c|c|c|}
\hline & \multicolumn{3}{|c|}{ Before PSM } & \multicolumn{3}{|c|}{ After PSM } \\
\hline & $\frac{\text { ACT }}{(n=148, \%)}$ & $\frac{\text { Observation }}{(\mathrm{n}=\mathbf{7 4}, \%)}$ & $P$ value & $\frac{\text { ACT }}{(n=65, \%)}$ & $\frac{\text { Observation }}{(\mathrm{n}=65, \%)}$ & $P$ value \\
\hline Age, $y$, (range) & $59(25-78)$ & $64(40-81)$ & $.001^{*}$ & $62(38-78)$ & $62(40-80)$ & $.882 \dagger$ \\
\hline $\begin{array}{l}\text { Sex, } \mathrm{n}(\%) \\
\quad \text { Female } \\
\text { Male }\end{array}$ & $\begin{array}{l}71(48.0) \\
77(52.0)\end{array}$ & $\begin{array}{l}34(45.9) \\
40(54.1)\end{array}$ & $.776 \ddagger$ & $\begin{array}{l}30(46.2) \\
35(53.8)\end{array}$ & $\begin{array}{l}30(46.2) \\
35(53.8)\end{array}$ & $1.000 \S$ \\
\hline $\begin{array}{l}\text { Smoking history, n (\%) } \\
\text { Yes } \\
\text { No }\end{array}$ & $\begin{array}{r}37(25.0) \\
111(75.0)\end{array}$ & $\begin{array}{l}16(21.6) \\
58(78.4)\end{array}$ & $.578 \ddagger$ & $\begin{array}{l}16(24.6) \\
49(75.4)\end{array}$ & $\begin{array}{l}14(21.5) \\
51(78.5)\end{array}$ & $.793 \S$ \\
\hline $\begin{array}{l}\text { Cancer-related comorbidity, n (\%) } \\
\text { Yes } \\
\text { No }\end{array}$ & $\begin{array}{r}42(28.4) \\
106(71.6)\end{array}$ & $\begin{array}{l}30(40.5) \\
44(59.5)\end{array}$ & $.068+$ & $\begin{array}{l}20(30.8) \\
45(69.2)\end{array}$ & $\begin{array}{l}25(37.5) \\
40(61.5)\end{array}$ & $.430 \S$ \\
\hline $\begin{array}{l}\text { Pulmonary function } \\
\text { FEV1/FVC } \geq 70 \%\end{array}$ & $138(93.2)$ & $71(95.9)$ & $.419 \ddagger$ & $59(90.8)$ & $62(95.4)$ & $.661 \S$ \\
\hline $\begin{array}{l}\text { PET-CT, n (\%) } \\
\text { Yes } \\
\text { No }\end{array}$ & $\begin{array}{r}25(16.9) \\
123(83.1)\end{array}$ & $\begin{array}{r}9(12.2) \\
65(87.8)\end{array}$ & $.356 \ddagger$ & $\begin{array}{r}9(13.8) \\
56(86.2)\end{array}$ & $\begin{array}{r}7(10.8) \\
58(89.2)\end{array}$ & $.793 \S$ \\
\hline $\begin{array}{l}\text { Procedure } 1 \\
\text { Lobectomy } \\
\text { Sub-lobectomy }\end{array}$ & $\begin{array}{c}142(95.9) \\
6(4.1)\end{array}$ & $\begin{array}{r}66(89.2) \\
8(10.8)\end{array}$ & $.051 \ddagger$ & $\begin{array}{c}60(92.3) \\
5(7.7)\end{array}$ & $\begin{array}{c}63(96.9) \\
2(3.1)\end{array}$ & $.727 \S$ \\
\hline $\begin{array}{l}\text { Procedure } 2 \\
\text { VATS } \\
\text { Open }\end{array}$ & $\begin{array}{r}126(85.1) \\
22(14.9)\end{array}$ & $\begin{array}{l}62(83.8) \\
12(16.2)\end{array}$ & $.792 \ddagger$ & $\begin{array}{r}57(87.7) \\
8(12.3)\end{array}$ & $\begin{array}{l}54(83.1) \\
11(16.9)\end{array}$ & $.661 \S$ \\
\hline $\begin{array}{l}\mathrm{P} \text { or } \mathrm{C} \\
\mathrm{P} \\
\mathrm{C}\end{array}$ & $\begin{array}{c}142(95.9) \\
6(4.1)\end{array}$ & $\begin{array}{c}72(97.3) \\
2(2.7)\end{array}$ & $.722 \|$ & $\begin{array}{c}60(92.3) \\
5(7.7)\end{array}$ & $\begin{array}{c}63(96.9) \\
2(3.1)\end{array}$ & $.727 \S$ \\
\hline $\begin{array}{l}\text { Postoperative complication, n (\%) } \\
\text { Yes } \\
\text { No }\end{array}$ & $\begin{array}{c}2(1.4) \\
146(98.6)\end{array}$ & $\begin{array}{c}2(2.7) \\
72(97.3)\end{array}$ & $.602 \|$ & $\begin{array}{c}1(1.5) \\
64(98.5)\end{array}$ & $\begin{array}{c}1(1.5) \\
64(98.5)\end{array}$ & $1.000 \S$ \\
\hline $\mathrm{T}$ size, $\mathrm{cm} \pm \mathrm{SD}$ & $2.60 \pm 0.87$ & $2.71 \pm 0.87$ & $.282 *$ & $2.56 \pm 0.82$ & $2.60 \pm 0.78$ & $.726 \dagger$ \\
\hline $\begin{array}{l}\text { Histology, n }(\%) \\
\text { Adenocarcinoma } \\
\text { Nonadenocarcinoma }\end{array}$ & $\begin{array}{r}133(89.9) \\
15(10.1)\end{array}$ & $\begin{array}{c}69(93.2) \\
5(6.8)\end{array}$ & $.407 \ddagger$ & $\begin{array}{c}61(93.8) \\
4(6.2)\end{array}$ & $\begin{array}{c}60(92.3) \\
5(7.7)\end{array}$ & $.930 \S$ \\
\hline $\begin{array}{l}\text { Pleural invasion } \\
\text { Yes } \\
\text { No }\end{array}$ & $\begin{array}{l}60(40.5) \\
88(59.5)\end{array}$ & $\begin{array}{l}24(32.4) \\
50(67.6)\end{array}$ & $.240 \ddagger$ & $\begin{array}{l}26(40.0) \\
39(60.0)\end{array}$ & $\begin{array}{l}23(36.9) \\
42(63.1)\end{array}$ & $.661 \S$ \\
\hline
\end{tabular}

Nonadenocarcinoma includes squamous cell carcinoma, large cell carcinoma, and adenosquamous carcinoma. PSM, Propensity score matched; $A C T$, adjuvant chemotherapy; $F E V 1$, forced expiratory volume in 1 second; $F V C$, forced vital capacity; PET-CT, position emission tomography computed tomography; VATS, video-assisted thoracic surgery; $P$, peripheral lung cancer; $C$, central lung cancer; $S D$, standard deviation. *Mann-Whitney $U$ test. $\nmid$ Paired-samples $t$ test. $\ddagger$ Chi-square test. $\S$ McNemar's test. $\|$ Fisher exact test.

(HR, 2.01; 95\% CI, 1.13-3.60; $P=.018$ ). In patients with stage IB, there were significant differences in RFS (HR, 1.68 ; 95\% CI, 1.16-2.41; $P=.006)$ and OS (HR, 1.87; $95 \% \mathrm{CI}, 1.19-2.94 ; P=.007$ ) (Figures E1 and E2).

\section{Adjuvant Chemotherapy Was Associated With Improved Survival of Patients With Stage I Non-Small Cell Lung Cancer With Lymphovascular Invasion}

Among all patients with stage I, 854 patients received at least 3-cycle cisplatin/carboplatin-based ACT. A total of 87 patients received vinorelbine, 48 patients received gemcitabine, 598 patients received docetaxel, and 121 patients received pemetrexed. Table 2 shows that ACT was not correlated with improved survival for all patients with stage I NSCLC (RFS: HR, 0.94; 95\% CI, 0.77-1.16; $P=.588$; OS: HR, 1.22; 95\% CI, 0.95-1.55; $P=.119$ ).

To identify whether ACT could improve the survival of patients with stage I NSCLC with LVI, we further divided the LVI-P group into 2 subgroups: the surgery alone group (observation group) and the ACT group. A total of 148 patients received ACT after surgery, of whom 67 had stage 
TABLE 4. Multivariate analyses of prognostic factors of patients with stage I non-small cell lung cancer with lymphovascular invasion after propensity score matching

\begin{tabular}{|c|c|c|c|c|}
\hline & \multicolumn{2}{|c|}{ Multivariate analysis of RFS } & \multicolumn{2}{|c|}{ Multivariate analysis of OS } \\
\hline & HR (95\% CI) & $P$ value & HR $(95 \%$ CI $)$ & $P$ value \\
\hline Age, y(range) & $1.04(0.99-1.09)$ & .073 & $1.06(1.00-1.12)$ & .046 \\
\hline \multicolumn{5}{|l|}{ Sex } \\
\hline Female & $0.76(0.35-1.64)$ & .484 & $0.88(0.43-2.99)$ & .793 \\
\hline \multicolumn{5}{|l|}{ Smoking history } \\
\hline Yes & $2.15(0.95-4.88)$ & .067 & $1.79(0.66-4.85)$ & .067 \\
\hline \multicolumn{5}{|c|}{ Cancer-related comorbidity } \\
\hline Yes & $1.25(0.59-2.68)$ & .561 & $1.12(0.43-2.88)$ & .820 \\
\hline \multicolumn{5}{|l|}{ Pulmonary function } \\
\hline FEV $1 / F V C \geq 70 \%$ & $0.34(0.04-2.67)$ & .306 & $0.64(0.08-5.46)$ & .683 \\
\hline \multicolumn{5}{|l|}{ PET-CT } \\
\hline Yes & $0.96(0.37-2.48)$ & .936 & $1.94(0.53-7.02)$ & .315 \\
\hline \multicolumn{5}{|l|}{ Procedure 1} \\
\hline Lobectomy & $0.44(0.10-1.92)$ & .276 & $0.53(0.09-3.01)$ & .475 \\
\hline \multicolumn{5}{|l|}{ Procedure 2} \\
\hline VATS & $0.65(0.24-1.79)$ & .402 & $1.06(0.34-3.28)$ & .921 \\
\hline \multicolumn{5}{|l|}{$\mathrm{P}$ or $\mathrm{C}$} \\
\hline $\mathrm{P}$ & $0.60(0.06-5.68)$ & .656 & $0.74(0.07-7.63)$ & .799 \\
\hline \multicolumn{5}{|c|}{ Postoperative complication } \\
\hline Yes & $1.29(0.15-11.43)$ & .820 & $0.73(0.07-7.29)$ & .790 \\
\hline $\mathrm{T}$ size & $1.35(0.86-2.13)$ & .197 & $1.34(0.76-2.36)$ & .311 \\
\hline \multicolumn{5}{|l|}{ Histology } \\
\hline Adenocarcinoma & $0.52(0.16-1.72)$ & .282 & $0.37(0.10-1.34)$ & .130 \\
\hline \multicolumn{5}{|l|}{ Pleural invasion } \\
\hline Yes & $7.32(0.98-54.42)$ & .052 & $5.90(0.77-45.19)$ & .087 \\
\hline \multicolumn{5}{|l|}{ TNM stage } \\
\hline IB & $8.47(0.91-78.69)$ & .060 & $8.06(0.75-86.56)$ & .085 \\
\hline \multicolumn{5}{|l|}{$\mathrm{ACT}$} \\
\hline Yes & $0.33(0.16-0.67)$ & .002 & $0.30(0.12-0.74)$ & .009 \\
\hline
\end{tabular}

Nonadenocarcinoma includes squamous cell carcinoma, large cell carcinoma, and adenosquamous carcinoma. RFS, Recurrence-free survival; $O S$, overall survival; $H R$, hazard ratio; $C I$, confidence interval; $F E V 1$, forced expiratory volume in 1 second; $F V C$, forced vital capacity; PET-CT, position emission tomography computed tomography; VATS, video-assisted thoracoscopic surgery; $P$, peripheral lung cancer; $C$, central lung cancer; $T N M$ stage, tumor-node-metastasis stage; $A C T$, adjuvant chemotherapy.

IA disease and 81 had stage IB disease. The patients who accepted chemotherapy tended to be younger. The basic patient characteristics of both groups are shown in Table 3. There was no significance in the distribution in other clinical characteristics. A PSM analysis was implemented to reduce the selection bias. Finally, 65 pairs of patients were included in the analysis. The results of multivariate analysis for all matched patients are summarized in Table 4.

For all patients with stage I with LVI, after adjustment for other clinical variables, including sex, age, smoking history, comorbidities, pulmonary function, PET-CT examination, extent of surgery, histology, VPI, locations, postoperative complication, and TNM stage, multivariable analysis indicated that ACT was associated with increased RFS (HR, 0.33; 95\% CI, 0.16-0.67; $P=.002$ ) and OS (HR, 0.30; $95 \% \mathrm{CI}, 0.12-0.74 ; P=.009$ ) (Figure $3, A$ and $B$ ). To identify the ACT benefits in patients with stage IA1-3 and patients with stage IB with LVI, we also conducted a subgroup analysis. ACT was associated with statistically improved RFS (HR, 0.21 ; 95\% CI, 0.06-0.69; $P=.011$ ) and OS (HR, 0.09; $95 \%$ CI, $0.01-0.67 ; P=.018$ ) for those with stage IA1-3 and improved RFS (HR, 0.37; 95\% CI, 0.14-0.94; $P=.037$ ) and OS (HR, 0.26; 95\% CI, 0.09-0.78; $P=.018$ ) for those with stage IB with LVI (Figures E3 and E4).

\section{DISCUSSION}

This study investigated the prognostic effect of LVI in stage I NSCLC using the 8th edition of the TNM classification and explored the survival benefits from ACT in such patients. Our primary results suggested that LVI was an independent negative prognostic factor in patients with stage I NSCLC. We also found that ACT was associated 


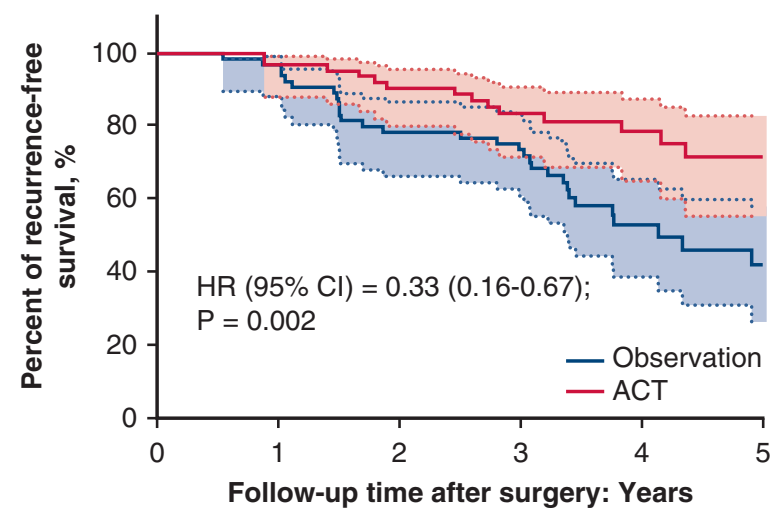

No. of risk

$\begin{array}{lllllll}\text { ACT } & 65 & 61 & 52 & 36 & 21 & 11\end{array}$

Observation 65

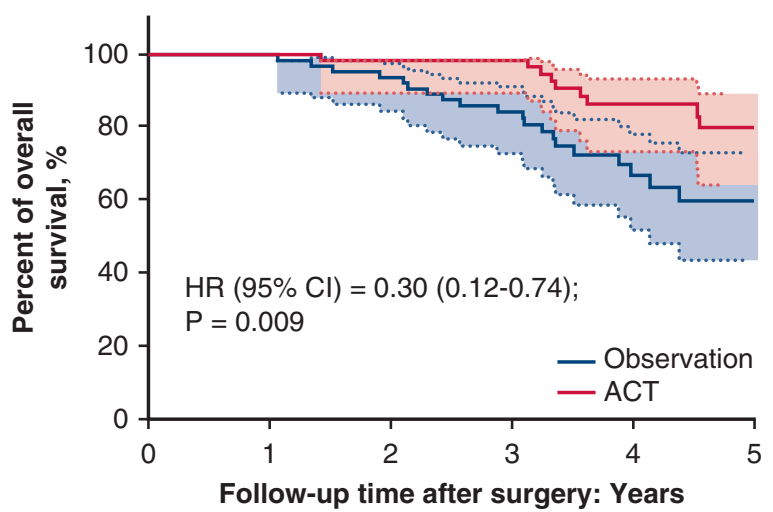

No. of risk $\begin{array}{lllllll}\text { ACT } & 65 & 65 & 60 & 48 & 27 & 15\end{array}$ $\begin{array}{lllllll}\text { Observation } & 65 & 65 & 59 & 41 & 19 & 10\end{array}$

B

FIGURE 3. RFS (A) and OS (B) curves (ACT vs observation) of all patients with stage I NSCLC with LVI. ACT, Adjuvant chemotherapy; HR, hazard ratio; CI, confidence interval.

with improved outcomes in patients with stage I NSCLC with LVI.

In previous studies, LVI has been demonstrated to be an unfavorable significant prognostic factor in patients with stage I NSCLC. LVI can be divided into blood vessel invasion and lymphatic vessel invasion. Both of them were reported to be significant prognostic factors in the studies by Gabor and colleagues ${ }^{25}$ and Brechot and colleagues. ${ }^{26}$ In recent years, several relatively large-scale studies demonstrated that the OS of patients with stage IA with LVI overlapped that of those with stage IB without LVI. The study by Tsuchiya and colleagues ${ }^{27}$ in Japan directly demonstrated that the prognosis of patients with stage IA NSCLC with LVI was similar to that of patients with stage IB NSCLC without LVI. ${ }^{27}$ This was confirmed in a larger study from Naito and colleagues. ${ }^{12}$ The study included 826 patients with stage I with NSCLC, of whom 279 had LVI. Because of the poor OS of patients with stage I with LVI, several studies suggest including LVI in the T grade. ${ }^{14,28}$ However, this was not included in the newest 8th TNM staging. It is possible that more evidence is needed for LVI to be a factor in upstaging.

Although there is no definite consensus on the use of ACT for stage I NSCLC, several clinical trials and metaanalysis recommend $\mathrm{ACT}$ for patients with resected stage II and IIIA NSCLC. The use of ACT is still controversial in patients with stage IB. Cancer and Leukemia Group B 9633 recommended ACT for patients with stage IB whose tumor size was $4 \mathrm{~cm}$ or greater. The other 2 studies, JBR.10 and ANITA, showed no beneficial survival from ACT in patients with stage IB. Meanwhile, the use of ACT in patients with stage IA NSCLC is not clear yet. The most famous study was from Japan, ${ }^{18}$ demonstrating that oral uracil-tegafur was effective for patients with stage
I NSCLC, particularly when the tumor was $2 \mathrm{~cm}$ or larger. A meta-analysis also showed a proven benefit of ACT, but failed to find an advantage in patients with stage IA. ${ }^{29} \mathrm{How}-$ ever, a study from Tsuchiya and colleagues ${ }^{27}$ demonstrated that oral uracil-tegafur chemotherapy significantly increased the 5-year survival of the stage IA vascular invasion group by more than $25 \%$ and was the first study to show a benefit from ACT. In 2014, another study from Tsutani and colleagues ${ }^{30}$ found that ACT was effective in patients with stage I NSCLC, particularly those with an invasive component larger than $2 \mathrm{~cm}$ or with lymphatic invasion. ${ }^{30}$ The benefit from ACT in patients with stage IA is still unclear. Because of the heterogeneity of stage I NSCLC, finding optimal candidates for ACT should be the appropriate strategy. In our center, ACT was recommended for patients with stage IB with high-risk factors according to NCCN guidelines. For the patients with stage IA, some specialists suggested ACT for patients with risk factors, such as LVI based on the previous studies. ${ }^{18,30}$ When the pathologic findings were reported, a case-based learning was held in the medical team and the decision was made. In our study, a relatively large-scale study, we compared OS and RFS between LVI-P patients who received ACT and surgery alone and found that adjuvant therapy could be beneficial in this subset. Especially for patients with stage I with LVI, ACT was associated with improved survival.

\section{Study Limitations}

There were some limitations in our study. First, the study had an insufficient patient cohort; therefore, a homogeneous cohort and selection bias are inevitable because it is a retrospective study. Although we performed PSM to eliminate the selection bias as much as possible, there are some 
unrecognized confounders, such as the economic capability of patients and the cultural education of patients and disposition from the hospital. Second, in our study, we excluded micro-invasive carcinoma; such patients have a good prognosis but this might have influenced our results. Third, we did not distinguish blood vessels from lymphatic vessels, because several studies determined both were unfavorable significant prognostic factors, whereas the others did not. ${ }^{10,13,26}$ Fourth, the mechanism of benefit from ACT is still uncertain. In our study, we defined 3- to 4-cycle treatment as effective chemotherapy, but we did not explore the relationship among regimens, dosage and toxicity, and survival. Last but not least, the gene status and postrecurrence treatment are unclear in our study. Further prospective studies are needed to validate the results.

\section{CONCLUSIONS}

Our study indicated that LVI was a strong prognostic factor in patients with stage I NSCLC, and ACT was associated with improved OS in patients with stage I with LVI. For pathologic LVI-P patients, either stage IA or stage IB, the application of ACT might be a more appropriate choice.

\section{Conflict of Interest Statement}

Authors have nothing to disclose with regard to commercial support.

The authors thank the Department of Pathology of Shanghai Chest Hospital for support and the patients and their families for their contributions to this study.

\section{References}

1. Torre LA, Bray F, Siegel RL, Ferlay J, Lortet-Tieulent J, Jemal A. Global cancer statistics, 2012. CA Cancer J Clin. 2015;65:87-108.

2. National Lung Screening Trial Research Team, Aberle DR, Adams AM, Berg CD, Black WC, Clapp JD, et al. Reduced lung-cancer mortality with low-dose computed tomographic screening. N Engl J Med. 2011;365:395-409.

3. Goldstraw P, Chansky K, Crowley J, Rami-Porta R, Asamura H, Eberhardt WE, et al. The IASLC lung cancer staging project: proposals for revision of the TNM stage groupings in the forthcoming (eighth) edition of the TNM classification for lung cancer. J Thorac Oncol. 2016;11:39-51.

4. Yang P, Allen MS, Aubry MC, Wampfler JA, Marks RS, Edell ES, et al. Clinical features of 5,628 primary lung cancer patients: experience at Mayo Clinic from 1997 to 2003. Chest. 2005;128:452-62.

5. Naruke T, Goya T, Tsuchiya R, Suemasu K. Prognosis and survival in resected lung carcinoma based on the new international staging system. J Thorac Cardiovasc Surg. 1988;96:440-7.

6. Igai H, Matsuura N, Tarumi S, Chang SS, Misaki N, Ishikawa S, et al. Prognostic factors in patients after lobectomy for p-T1aN0M0 adenocarcinoma. Eur J Cardiothorac Surg. 2012;41:603-6.

7. Higgins KA, Chino JP, Ready N, D'Amico TA, Berry MF, Sporn T, et al. Lymphovascular invasion in non-small-cell lung cancer: implications for staging and adjuvant therapy. $J$ Thorac Oncol. 2012;7:1141-7.

8. Hung JJ, Jeng WJ, Hsu WH, Chou TY, Huang BS, Wu YC. Predictors of death, local recurrence, and distant metastasis in completely resected pathological stage-I non-small-cell lung cancer. J Thorac Oncol. 2012;7: 1115-23.

9. Yoshida J, Nagai K, Asamura H, Goya T, Koshiishi Y, Sohara Y, et al. Japanese joint committee for lung cancer registration. Visceral pleura invasion impact on non-small cell lung cancer patient survival: its implications for the forthcoming
TNM staging based on a large-scale nation-wide database. J Thorac Oncol. 2009; 4:959-63.

10. Maeda R, Yoshida J, Ishii G, Hishida T, Aokage K, Nishimura M, et al. Longterm survival and risk factors for recurrence in stage I non-small cell lung cancer patients with tumors up to $3 \mathrm{~cm}$ in maximum dimension. Chest. 2010;138: $357-62$.

11. Maeda R, Yoshida J, Ishii G, Hishida T, Nishimura M, Nagai K. Poor prognostic factors in patients with stage IB non-small cell lung cancer according to the seventh edition TNM classification. Chest. 2011;139:855-61.

12. Naito Y, Goto K, Nagai K, Ishii G, Nishimura M, Yoshida J, et al. Vascular invasion is a strong prognostic factor after complete resection of node-negative nonsmall cell lung cancer. Chest. 2010;138:1411-7.

13. Hanagiri T, Takenaka M, Oka S, Shigematsu Y, Nagata Y, Shimokawa H, et al. Prognostic significance of lymphovascular invasion for patients with stage I non-small cell lung cancer. Eur Surg Res. 2011;47:211-7.

14. Ruffini E, Asioli S, Filosso PL, Buffoni L, Bruna MC, Mossetti C, et al. Significance of the presence of microscopic vascular invasion after complete resection of Stage I-II pT1-T2N0 non-small cell lung cancer and its relation with T-Size categories: did the 20097 th edition of the TNM staging system miss something? J Thorac Oncol. 2011;6:319-26.

15. Douillard JY, Rosell R, De Lena M, Carpagnano F, Ramlau R, GonzalesLarriba JL, et al. Adjuvant vinorelbine plus cisplatin versus observation in patients with completely resected stage IB-IIIA non-small-cell lung cancer (Adjuvant Navelbine International Trialist Association [ANITA]): a randomised controlled trial. Lancet Oncol. 2006;7:719-27.

16. Butts CA, Ding K, Seymour L, Twumasi-Ankrah P, Graham B, Gandara D, et al. Randomized phase III trial of vinorelbine plus cisplatin compared with observation in completely resected stage IB and II non-small-cell lung cancer: updated survival analysis of JBR-10. J Clin Oncol. 2010;28:29-34.

17. Strauss GM, Herndon JN, Maddaus MA, Johnstone DW, Johnson EA, Harpole DH, et al. Adjuvant paclitaxel plus carboplatin compared with observation in stage IB non-small-cell lung cancer: CALGB 9633 with the cancer and leukemia group B, radiation therapy oncology Group, and North Central cancer treatment group study groups. J Clin Oncol. 2008; 26:5043-51.

18. Kato H, Ichinose Y, Ohta M, Hata E, Tsubota N, Tada H, et al. A randomized trial of adjuvant chemotherapy with uracil-tegafur for adenocarcinoma of the lung. N Engl J Med. 2004;350:1713-21.

19. Hamada C, Tsuboi M, Ohta M, Fujimura S, Kodama K, Imaizumi M, et al. Effect of postoperative adjuvant chemotherapy with tegafur-uracil on survival in patients with stage IA non-small cell lung cancer: an exploratory analysis from a meta-analysis of six randomized controlled trials. J Thorac Oncol. 2009;4: 1511-6.

20. Hamada C, Tanaka F, Ohta M, Fujimura S, Kodama K, Imaizumi M, et al. Metaanalysis of postoperative adjuvant chemotherapy with tegafur-uracil in nonsmall-cell lung cancer. J Clin Oncol. 2005;23:4999-5006.

21. Battafarano RJ, Piccirillo JF, Meyers BF, Hsu H, Guthrie TJ, Cooper JD, et al. Impact of comorbidity on survival after surgical resection in patients with stage I non-small cell lung cancer. J Thorac Cardiovasc Surg. 2002; 123:280-7.

22. Iachina M, Green A, Jakobsen E. The direct and indirect impact of comorbidity on the survival of patients with non-small cell lung cancer: a combination of survival, staging and resection models with missing measurements in covariates. BMJ Open. 2014;4:e3846.

23. Zhai R, Yu X, Shafer A, Wain JC, Christiani DC. The impact of coexisting COPD on survival of patients with early-stage non-small cell lung cancer undergoing surgical resection. Chest. 2014;145:346-53.

24. Ettinger DS, Wood DE, Akerley W, Bazhenova LA, Borghaei H, Camidge DR, et al. NCCN guidelines insights: non-small cell lung cancer, version 4.2016. J Natl Compr Canc Netw. 2016;14:255-64.

25. Gabor S, Renner H, Popper H, Anegg U, Sankin O, Matzi V, et al. Invasion of blood vessels as significant prognostic factor in radically resected T13NOM0 non-small-cell lung cancer. Eur J Cardiothorac Surg. 2004;25: 439-42.

26. Brechot JM, Chevret S, Charpentier MC, Appere De Vecchi C, Capron F, Prudent J, et al. Blood vessel and lymphatic vessel invasion in resected nonsmall cell lung carcinoma. Correlation with TNM stage and disease free and overall survival. Cancer. 1996;78:2111-8.

27. Tsuchiya T, Akamine S, Muraoka M, Kamohara R, Tsuji K, Urabe S, et al. Stage IA non-small cell lung cancer: vessel invasion is a poor prognostic factor and a new target of adjuvant chemotherapy. Lung Cancer. 2007;56:341-8. 
28. Kudo Y, Saji H, Shimada Y, Matsubayashi J, Nagao T, Kakihana M, et al. Proposal on incorporating blood vessel invasion into the $\mathrm{T}$ classification parts as a practical staging system for stage I non-small cell lung cancer. Lung Cancer. 2013;81:187-93.

29. Tsuboi M, Ohira T, Saji H, Miyajima K, Kajiwara N, Uchida O, et al. The present status of postoperative adjuvant chemotherapy for completely resected non-small cell lung cancer. Ann Thorac Cardiovasc Surg. 2007; 13:73-7.
30. Tsutani Y, Miyata Y, Kushitani K, Takeshima Y, Yoshimura M, Okada M. Propensity score-matched analysis of adjuvant chemotherapy for stage I non-small cell lung cancer. J Thorac Cardiovasc Surg. 2014;148:1179-85.

Key Words: adjuvant chemotherapy, lymphovascular invasion, non-small cell lung cancer, Stage I, visceral pleura invasion 


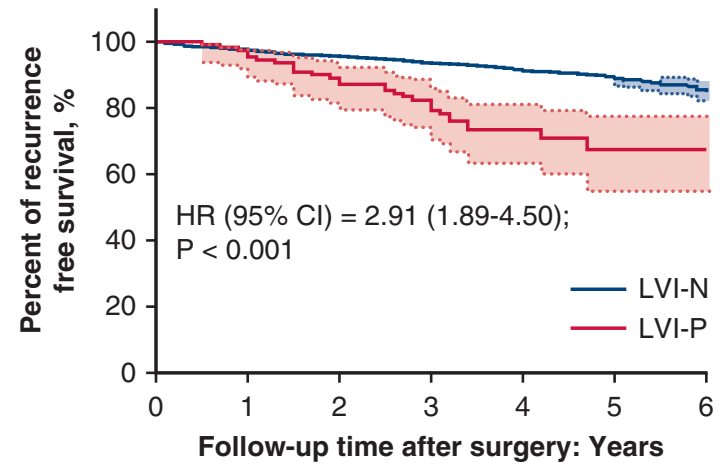

No. of risk

LVI-N $1476 \quad 1431 \quad 1395 \quad 1081 \quad 589 \quad 272 \quad 106$

LVI-P $\quad 112 \quad 107 \quad 91 \quad 60 \quad 26 \quad 11 \quad 4$

A

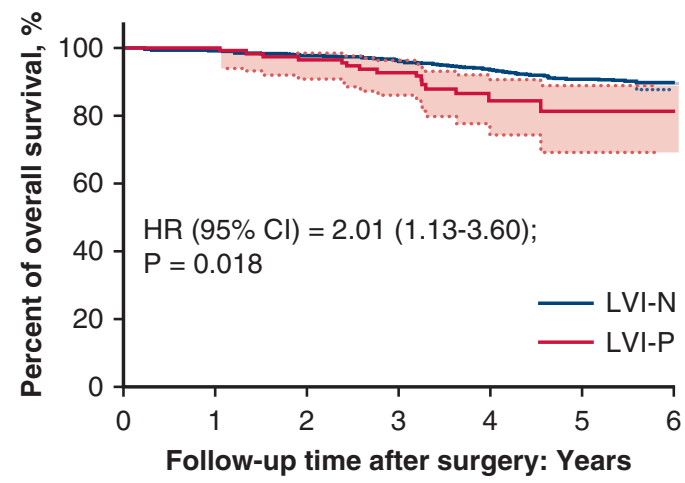

No. of risk

$\begin{array}{llllllll}\text { LVI-N } & 1482 & 1472 & 1445 & 1167 & 689 & 346 & 168\end{array}$

$\begin{array}{llllllll}\text { LVI-P } & 113 & 113 & 102 & 69 & 30 & 13 & 5\end{array}$

B

FIGURE E1. RFS (A) and OS (B) curves of patients with stage IA1-3 stratified by LVI. LVI-N, Lymphovascular invasion negative; LVI-P, lymphovascular invasion positive; $H R$, hazard ratio; $C I$, confidence interval.

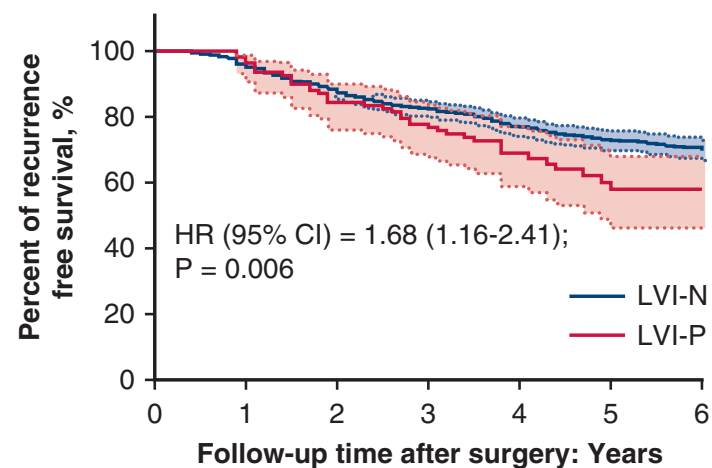

No. of risk

$\begin{array}{llllllll}\text { LVI-N } & 920 & 869 & 799 & 714 & 555 & 375 & 226\end{array}$

$\begin{array}{llllllll}\text { LVI-P } & 109 & 106 & 89 & 67 & 40 & 22 & 12\end{array}$

A

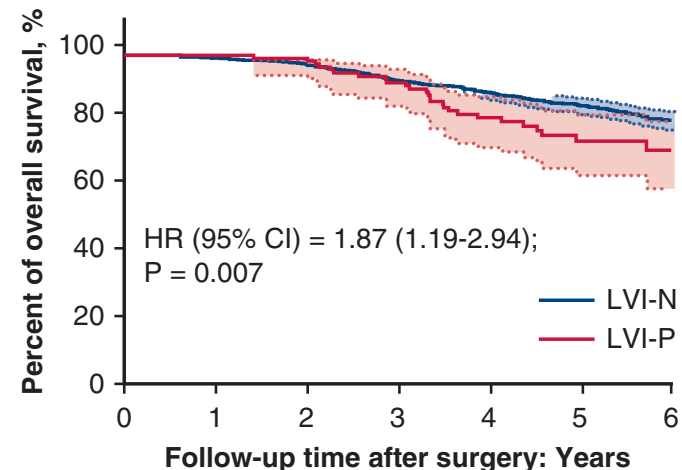

No. of risk

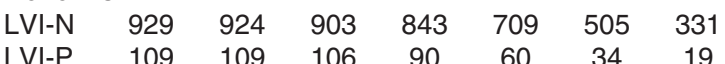

B

FIGURE E2. RFS (A) and OS (B) curves of patients with stage IB stratified by LVI. LVI-N, Lymphovascular invasion negative; LVI-P, lymphovascular invasion positive; $H R$, hazard ratio; $C I$, confidence interval. 


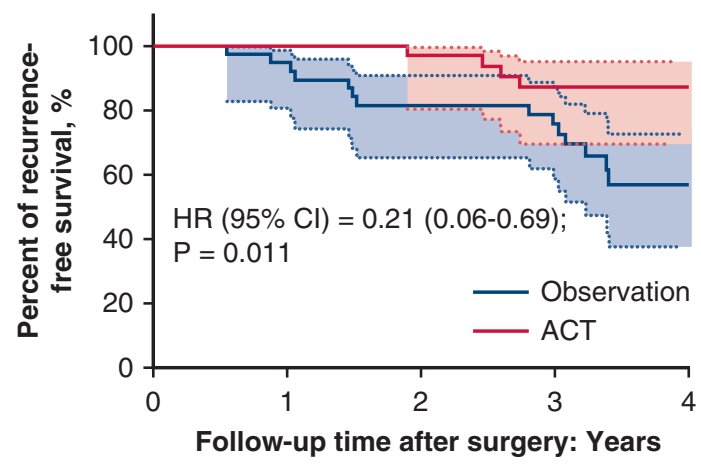

No. of risk

$\begin{array}{llllll}\text { ACT } & 35 & 34 & 29 & 18 & 9\end{array}$

Observation 38

A

FIGURE E3. RFS (A) and OS (B) curves (ACT vs observation) of patients with stage IA1-3 with LVI. ACT, Adjuvant chemotherapy; $H R$, hazard ratio; $C I$, confidence interval.

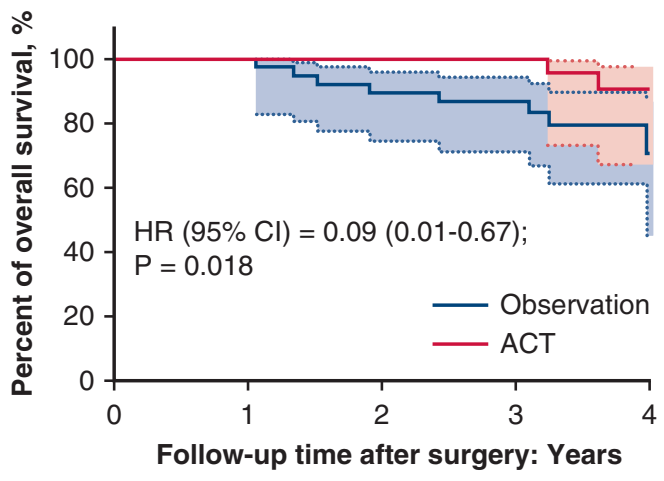

No. of risk

$\begin{array}{llllll}\text { ACT } & 35 & 35 & 32 & 22 & 10\end{array}$

$\begin{array}{llllll}\text { Observation } & 38 & 38 & 32 & 20 & 7\end{array}$

B

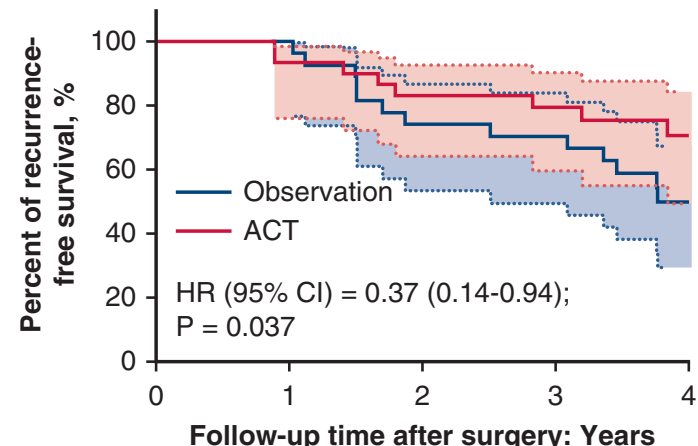

No. of risk

ACT $\quad 30$

Observation 27

A

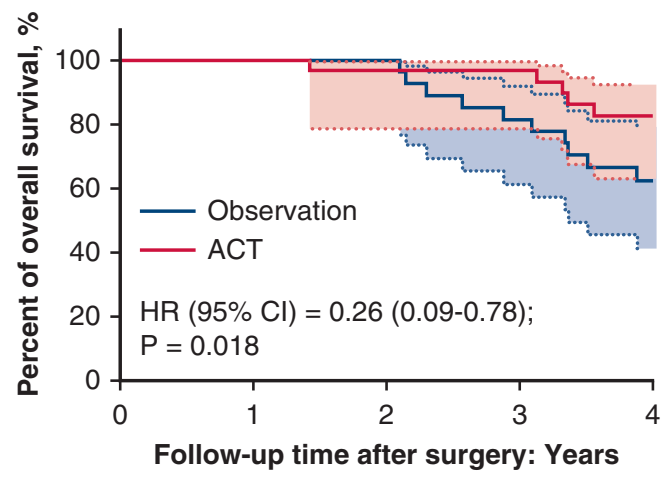

No. of risk

$\begin{array}{llllll}\text { ACT } & 30 & 30 & 29 & 26 & 17\end{array}$

Observation $27 \quad 27 \quad 27 \quad 21 \quad 12$

FIGURE E4. RFS (A) and OS (B) curves (ACT vs observation) of patients with stage IB with LVI. ACT, Adjuvant chemotherapy; $H R$, hazard ratio; $C I$, confidence interval. 